\title{
Food Security and Floodplain Irrigation: The Case of Dominion Irrigation Project in Yala Swamp, Siaya County, Kenya
}

\author{
Patriciah I. Owiyo \\ Moi University, College of Health Sciences, P.O. Box 4606-30100, Eldoret, Kenya
}

\begin{abstract}
In 2003 the regional government authorities of Siaya District granted a 25-year lease for rice cultivation to Dominion Farms (K) Ltd, a subsidiary of Dominion Group of Companies based in Edmond, Oklahoma, USA. The agreement as approved by the then local authorities of Bondo and Siaya County Councils was that Dominion Irrigation Project would engage in rice production in part of the swamp known as Area I, covering about 2,300 ha. However, instead of the originally intended rice cultivation in the 2,300 ha once owned by the Lake Basin Development Authority (LBDA), Dominion embarked on other additional agricultural and development activities in the swamp that went beyond rice cultivation. This included construction of water control dykes, weirs, canals, dams as well as an air strip and road. The Project also engaged in a major aquaculture venture which included fish farms, a fish processing and fish mill factories. For this purpose, the Project required more land and so it engaged in compulsory acquisition of extra land and in the process displacing families from their homes and farms. For the wetland community of Yala Swamp this meant the loss of a natural resource that had ensured food security for the households for generations. These activities undertaken by Dominion Farms (K) Ltd elicited mixed reactions with a number of stakeholders voicing various concerns over non-inclusion in the talks, forceful evacuation and inadequate compensation. The more critical cause for concern for this riparian community was however the loss of food security.
\end{abstract}

Keywords: Dominion Irrigation Project; Food Security, Yala Swamp

\section{Introduction}

Food security means increasing food production and addressing the root causes of vulnerability through a range of interventions, including rural development, agricultural research and building livelihoods. Food security is achieved when all people, at all times, have physical and economic access to sufficient, safe and nutritious food to meet their dietary needs and food preferences for an active and healthy life (FAO, 2012; Kiome, 2009). Kenya has only about 17 percent of its area classified as medium to high potential land and thus suitable for rain-fed agriculture. Thus the remaining arid and semi-arid land cannot reliably support agriculture unless technologies such as irrigation and water harvesting are employed. As Ngigi (2002) observes, food shortages in Kenya pose a recurrent crisis, which cannot be solved through rain-fed agricultural production alone. It would imply that supporting Kenya's rapidly increasing population requires the use of technologies such as irrigation to support agricultural intensification. This study was a response to discontent arising from a breakdown in the productive activities of the residents of South Central Alego Location - a breakdown caused by the take-over and transformation of Yala Swamp. Prior to the transformation in 2003, the Yala Swamp Wetland ensured sustainable household livelihoods, and more specifically food security to the riparian community through traditional livelihood activities like floodplain agriculture, fishing and herding.

\section{Literature Review}

Global food security is a worldwide concern and the challenge is how to feed a growing population which currently is estimated at 7.165 billion and projected to reach 9.2 billion by the year 2050. Barbier and Strand (2011) believe that food security can be made possible through more proactive and progressive policies and investments in both rural and agricultural productivity enhancement measures, and innovative safety nets that ensure access to food and reduction in the number of the hungry. As efforts are made towards achieving food security, technological advances or expansion of cultivated areas would boost production sufficiently to meet rising global food demands The developing world, while effecting their development programmes, lacks the necessary requisite skills and hence end up inviting foreign investors with advanced agricultural technology to effect development on wetlands and other fragile natural resources. While most of these are directed towards minerals and oil prospecting (due to encouraging high prices), farmlands and remaining wetlands have also been targets to produce cereals, horticultural crops and vegetables for export. According to DFID (2002), the challenge for governments and investors has been how to best effect these development programmes without interfering with the flow of traditional agricultural methods used by the local communities in floodplain areas. The current study believes another challenge would be how to best effect these development programmes in wetlands without necessarily plundering the natural resource bases. For the host government and local communities, the challenge comes when the aspect of technology transfer is ignored and agricultural land is depleted by the modern agricultural practices. Indeed in Yala Swamp the hard reality is that with the transformation of the Wetland, the flow of traditional agricultural methods and destruction of the environment was bound to happen since large-scale rice production would definitely take the form of mechanized farming and the use of chemicals.

Swallow (2004) shares the same sentiments expounded by NEMA (2005) when he acknowledges that the high population on the Lake Victoria Basin of Kenya relies 


\section{International Journal of Science and Research (IJSR) \\ ISSN (Online): 2319-7064 \\ Index Copernicus Value (2013): 6.14 | Impact Factor (2014): 5.611}

heavily on the wetlands in the region for their household livelihoods. Maltby (1991) observes that while rural communities have long recognized the value of wetlands as a resource for household livelihoods, the more economically ambitious world has seen them as wastelands to be filled and drained. Terer et al. (2004), Gichuki (2003) and Thenya (2006) hold that despite the realization and wide documentation of the importance of wetlands for biological, hydrological, economic and socio-ecological functions, wetlands are some of the most threatened ecosystems in the world. The views held by the above scholars correspond to the sentiments expressed at The Ramsar Convention of 1971 (an international treaty for the conservation and sustainable utilization of wetlands). Ramsar idea was to stem the progressive encroachment on and loss of wetlands, whilst recognizing the fundamental ecological functions of wetlands as well as the agricultural, economic, cultural, scientific and recreational values attached to the same (Ramsar Convention Secretariat, 2007).

Transformation of wetlands largely lead to losses to the wildlife and well-being of human communities especially in developing countries where many people continue to depend on wetlands and other natural resource bases for maintenance of traditional subsistence activities. While most developed countries have established controls restricting further wetland conversion, and even initiated habitat restoration, in many developing countries wetland conversion is seen as a strategy to gain more land for agricultural purposes. This study came into contact with an agitated riparian community that has continued to voice concern over the conversion of a wetland they had for generations considered to be their sole natural resource base. As Prossor (1995) notes, traditional societies have for centuries based their economic systems upon the natural rhythms of river regimes, especially in regions with long, dry spells and single, erratic wet seasons.

Adams (1995) and Oslon (2006) link poverty and population growth to invasion of wetlands by communities for agricultural and other income generating activities. Landberg (1994) did a study on population, economic development and poverty and concluded that the dependence of poor countries on their natural resources such as soil, water, wetlands, forests, animals and fisheries is selfevident. Indeed the growing populations in Sub-Saharan Africa, competition for fertile farming lands and limited access to resources has led to populations and investors invading wetlands and other marginal areas for agricultural and other transforming activities. In this fight for survival, they often engage in unsustainable use of these natural resources, causing degradation and other adverse effects. In the case of Kadenge Sub-Location, the current study was informed that the first inhabitants came from as far as Uganda through Lake Victoria to settle in the rich agricultural land, a land that was treasured because of its rich alluvial soil. It is the view of this study that population expansion and the need for fertile agricultural land is a major factor that leads to population migration towards wetlands. For investors, it is the desire to extract as much as they can of the natural resource that drives them to occupy and transform wetlands. As expected, such a scenario would place the Sub-Saharan Africa (SSA) governments in a position where they have to deal with growing populations as well as local and global investors determined to occupy and extract value from wetlands. This is because the value attached to wetlands would mostly be determined by the climatic and demographic factors prevailing in that particular area.

Asia leads as a continent where the poor have discovered that wetlands are not wastelands. According to Sarre and Blunden (1996), Asia produces $90 \%$ of the world's rice and $80 \%$ of this is associated with exploitation of wetland resources. In SSA where most economies are largely agrarian-based, the demand for arable farmlands continues to be a thorny issue for many countries. The scarce arable land faces competition as soils are becoming exhausted and water increasingly scarce. Poverty among the poorest proportion of the world's population leads to increased pressure on protected areas to supply land, water and other resources. The search for arable land has been identified by Oslon (2006) as one of the factors that drive communities into wetland resource exploitation for livelihood. In Kenya a number of wetlands have drawn populations by the rich alluvial soils and enough water for subsistence agriculture, livestock and household use. These include the: Mau Forest, Nyando Basin, Tana River Delta, Turkwel and Yala Swamp. In their fight for survival, households exploit natural habitats for livelihoods. The National Environment Management Authority (NEMA) (2005) observes that the riverine system provides the community members with both water and fodder for livestock, especially during the dry season. For instance, the estuarine community of Lokapel in Turkana cultivated the floodplains for food using both rain-fed and irrigated farming. Swallow (2004) shares the same sentiments expounded by NEMA (2005) when he acknowledges that the high population on the Lake Victoria Basin of Kenya relies heavily on the wetlands in the region for their household livelihoods.

Digby (2000) did a study on the Fulani community of northern Nigeria who have settled in and are cultivating the Hadejia-Nguru wetlands for food production. He states that the Fulani are self-sufficient in terms of food for domestic consumption and for commercial purposes. Like the Hadejia-Nguru wetlands, the Yala Swamp ensured food security for the residents of Yala Swamp in the period before the transformation in 2003. A study by Department of Resource Surveys and Remote Sensing (DRSRS) (1992) found that the swampy areas within the River Nyando estuary are potentially good agricultural land with rich alluvial soil. The study recommended that the Nyando Delta region should be developed by the estuarine community occupying the land. However, the DRSRS study does not give suggestions on how this potentially good agricultural land should be developed. It seems to imply that the more privileged in the region should apportion themselves large tracts of land and thereby 'develop' the area. In a developing country like Kenya this happens too often, and mostly to the disadvantage of the less privileged in society. For instance in the case of Dominion Project in Yala Swamp, the local community members claim the entrepreneur even disregarded the signed agreement and 'apportioned' himself more land by displacing the villagers from their homes, an action that led to sustained food insecurity in the region.

\section{Volume 4 Issue 12, December 2015}




\section{International Journal of Science and Research (IJSR)}

\section{Methodology and Study Area}

The study was carried out in Kadenge and Obambo SubLocations, South Central Alego Location, Boro Administrative Division, Siaya County, Kenya. A descriptive survey research design was used. This choice was pegged on the ability of a survey method to help in identifying standards against which existing conditions can be compared and also to determine the relations that exist between specific events. This design was very ideal in exploring the perceptions of the head of households in South Central Alego Location pertaining to the transformation of Yala Swamp Wetland.

Using proportionate random sampling techniques, the study interviewed 160 head of households using a semi-structured interview schedule in each of the two Sub-Locations of Kadenge and Obambo. These are persons who either directly or indirectly relied on the Yala Swamp Wetland for their household dietary needs, and who feel the transformation of the Wetland has affected their household livelihoods in one way or the other. Furthermore, 6 key informants who included the Chief, two Sub-Chiefs, the County Surveyor, the District Environmental/Forestry Officer and the District Agricultural Officer were purposively selected to provide additional and knowledgeable information pertaining to the study theme. The study used an interview schedule for the household heads and a key informant interview guide to interview the $6 \mathrm{key}$ informants. Statistical percentages and frequency distribution methods were used to display the various aspects of the statistical findings. Data collected from the key informants was compiled and analyzed separately at the level of descriptive statistics and then triangulated with that obtained from the head of households.

\section{Findings and Discussion}

\subsection{Staple Food (Cereal) within Yala Swamp Region}

Dominion Irrigation Project is basically a rice irrigation venture and so the study sought to know if rice is a staple food (cereal) in this region. When asked about their staple food it became clear that maize is indeed the staple food for this community as opposed to rice. $98.7 \%$ of the respondents explained that maize is their main cereal while rice is simply a supplement. Only $1.3 \%$ stated they take rice as the main cereal. This implies that Dominion rice is not actively boosting food security for the households. The District Agricultural Officer and the two Sub-Chiefs corroborated the information received from the head of households in terms of the staple cereal in the region.

\subsection{Source of Daily Food}

After establishing what the main foods consumed by the households in Kadenge and Obambo were, the study sought to find out the source of these foods. Data received revealed that $34 \%$ of the respondents get their foodstuff from subsistence farming while $66 \%$ purchase their foodstuff from the market. According to the local administration, this is very much unlike in the previous years when households got their foodstuff solely from the farm and even had excess to sell and meet other household needs.

\subsection{Availability of Land for Farming}

on the question of availability of land for subsistence farming, a vast majority of the household heads (98\%) lamented they do not have enough land to plough for subsistence agriculture and also for pasture. The District Agricultural Officer noted that there is a state of food insecurity and blamed it on lack of enough farming land for the households, as well as soil depletion from chemical use. The Chief and Sub-Chief for Kadenge were categorical that transforming Yala Swamp left the households without land to till for subsistence agriculture.

\subsection{Acquisition of Land by Dominion Farms (K) Ltd.}

It became practical to ascertain how Yala Swamp ended up in the hands of Dominion Farms (K) Ltd. The household heads and the key informants agreed that there is a lease agreement for acquisition of Area I (2,300 ha) but that the bone of contention lies with the signing of the agreement and the mode of occupation of extra land. They explained that they were not involved in the negotiations and that the officials at the then County Office and the Investor rushed the negotiations and signed the agreement without the consent of the residents. Table 4.1 shows the respondents' perspective on mode of acquisition of Area I.

Table 4.1: Acquisition of Area I

\begin{tabular}{|c|c|c|}
\hline Acquisition of Area I & Frequency & Percent \\
\hline None response & 5 & 3.1 \\
\hline Grabbed land & 46 & 28.8 \\
\hline Have no idea & 27 & 16.9 \\
\hline Through Corruption & 82 & 51.2 \\
\hline Total & 160 & 100.0 \\
\hline
\end{tabular}

Of the residents interviewed, $51.2 \%$ stated that the entrepreneur took over the land as a result of corruption involving himself, political leaders and the officials at the then Siaya County Council offices while $28.8 \%$ believe the investor disregarded everyone and simply grabbed the land. They explained that the Project disregarded their views and went ahead to erect beacons on the land. There is a further $16.9 \%$ of the respondents who had no idea and could not tell what transpired in 2003. All they know is that once they had land and now they don't.

The District Agricultural and Forestry/Environmental Officers both believe the land (Phase I and II) was held in trust by Siaya County Council on behalf of the local community. They confirmed the existence of a lease agreement but they were not eager to go into the politics of acquisition and transformation of the Wetland. The Chief and his two assistants decried the mode of acquisition of extra land. In as much as they appreciated that Area I was acquired through a signed agreement between the entrepreneur and the County Council officials, they maintained that the Project forcefully evicted some households, thereby disrupting the smooth flow of traditional livelihoods. What they see as a way forward is recorded in this report under recommendations. Only the County Surveyor expressed satisfaction with the mode of acquisition of Yala Swamp. He held the view that as the people's representatives, the politicians (area members of 


\section{International Journal of Science and Research (IJSR) \\ ISSN (Online): 2319-7064}

Index Copernicus Value (2013): 6.14 | Impact Factor (2014): 5.611

parliament and local authority officials) had the mandate to negotiate and sign a lease agreement on behalf of the locals.

\subsection{Affordability of Dominion Rice}

Asked if they are able to easily afford Dominion rice, a majority of respondents $(86.6 \%)$ stated that they cannot easily afford to purchase the rice for household use while only $13.8 \%$ stated they can easily afford to purchase the rice for both domestic and commercial purposes. However, the respondents who stated the rice is affordable hastened to explain that 'Prime Harvest Rice' per se is not affordable but the lower qualities - 'broken' and 'tips' are. 'Broken' derives its name from the pellets that break during processing and 'tips' are the tips of the pellets (smaller than 'broken'). 'Tips' was previously meant for chicken but on discovering that the locals feed on this, Dominion started selling the same to traders who re-sell to the locals. Also, it was noted that this response was received mainly from the female head of households. The explanation could be that female headed households are not too rigid about the availability of maize meal in their kitchens but easily supplement with other foods including rice.

\subsection{Modern Farming Technology Transfer}

Dominion Farms $(\mathrm{K}) \mathrm{Ltd}$ is a large scale irrigation venture employing mechanized farming for the production of rice for local consumption and also for export. It is therefore practical that the Project would be expected to pass some of this technical knowledge to the local community. Asked if the Project gives any form of training on modern agricultural methods, $18.1 \%$ of the respondents said there is training on farm machinery operations but went further to explain that this training is 'on-the-job'. According to this category of respondents, the training gives technical skills to the workers - some of whom can thereafter secure employment elsewhere - hence the training they receive while engaged by Dominion benefits the households. A further $21.9 \%$ felt the Project had served to ensure increased knowledge on irrigation methods. For this group, their wish was that Dominion should assist them (with finances and the technical know-how) practice irrigation on the semi-arid land they occupy presently. They claim the water from the river and lake should be enough to irrigate their small farms that lie on the periphery of the Swamp. $14.4 \%$ appreciated the on-the-job knowledge they get as workers in the fish ponds, rice farms etc. They believe they can tap increased knowledge on modern farming methods. However, as can be seen from Table 4.2 below $45.6 \%$ of the respondents believe the Project has not promoted technology transfer in the region and that the local farmers cannot boast of added knowledge on modern agricultural practices.

Table 4.2: Modern Farming Technology Transfer

\begin{tabular}{|c|c|c|}
\hline & Frequency & Percent \\
\hline $\begin{array}{c}\text { No technology transfer } \\
\text { Increased knowledge of irrigation farming } \\
\text { methods }\end{array}$ & 33 & 45.6 \\
\hline Knowledge of aquaculture & 23 & 21.9 \\
\hline On the job training on machine operations & 29 & 14.4 \\
\hline Total & 160 & 100.0 \\
\hline
\end{tabular}

\subsection{Food Situation before the Transformation of Yala Swamp Wetland}

Having explored the aspects of main foods consumed by the households in South Central Alego, availability of land and food security, the study sought to finalize by asking the respondents to make a comparison and give their assessment of the food situation in their households before and after the transformation of the Wetland. They were asked to explain what they thought contributed to food availability before Dominion took over and transformed the Wetland. Their perspectives on this are summarized in Table 4.3 below.

Table 4.3: Food situation before transformation of Wetland

\begin{tabular}{|c|c|c|}
\hline $\begin{array}{c}\text { Food Situation Before Transformation of } \\
\text { Wetland }\end{array}$ & Frequency & Percent \\
\hline It was bad & 5 & 3.1 \\
\hline $\begin{array}{c}\text { It was good: there was enough pasture } \\
\text { It was good: there was enough arable land for } \\
\text { farming }\end{array}$ & 52 & 32.5 \\
\hline Total & 103 & 64.4 \\
\hline
\end{tabular}

A majority of $64.4 \%$ explained that previously they had more than enough land for subsistence farming and for grazing their livestock. They narrated how people came from neighbouring locations and beyond to farm on the swampland. Apparently these 'neighbours' were welcomed because the swamp was vast and quite fertile; $32.5 \%$ explained that because there was adequate grazing land, they kept large herds of livestock which also translated into income for other household use. A small percentage (3.1\%) of the respondents stated that for them the food situation was bad even before the transformation of the wetland. They explained that their ancestors did not own farms within the wetland proper and so their farms (which are on the edge of the wetland) are not productive. The study noted that this percentage comprised mainly of persons from Obambo SubLocation - which is further from River Yala.

\subsection{Current Food Situation in the Wetland}

Having received the views of the respondents concerning the food situation in their households before Dominion took over the Wetland, the study went further to ask what they thought about the current food situation in their households. Table 4.4 gives the views of the household heads on the prevailing food situation in the study area.

Table 4.4: Current Food Situation

\begin{tabular}{|c|c|c|}
\hline & Frequency & Percent \\
\hline Good & 5 & 3.2 \\
\hline Adequate & 20 & 12.5 \\
\hline Bad & 135 & 84.3 \\
\hline Total & 160 & 100 \\
\hline
\end{tabular}

A vast majority of $84.3 \%$ of the respondents felt the current food situation is bad. They explained that when Dominion started in 2003, the Project provided maize seeds to the local farmers and even ploughed family plots, in addition to supplying the households with a sack of maize crop per household during the first harvest. They said all this stopped after the first year and the situation became dire. $12.5 \%$ stated the prevailing food situation is adequate and 3.2\% stated it is good. These last two categories (15.7\%) 


\section{International Journal of Science and Research (IJSR) \\ ISSN (Online): 2319-7064 \\ Index Copernicus Value (2013): 6.14 | Impact Factor (2014): 5.611}

explained that: they had managed to get small plots within Area I which they are tilling for subsistence food; they are financially able to access organic fertilizer from Dominion and this improves their yield to a small extent; they supplement whatever foods they harvest from their farms with Dominion rice; some members of their households are engaged in trade and from the proceeds, they are able to purchase more food from the market.

Based on the data received and analyzed the study established that the households of South Central Alego enjoyed food security in the period before the transformation of Yala Swamp. It further established that the households of South Central Alego have been faced with the problem of food security from the year 2003 when Dominion Irrigation Project took over the Yala Swamp Wetland.

\section{Discussion}

As Ngigi (2002) posits, food shortages in Kenya pose a recurrent crisis, which cannot be solved through rain-fed agricultural production alone. Indeed the arid and semi-arid parts of Kenya cannot reliably support agriculture unless technologies such as irrigation and water harvesting are employed. What Dominion is doing in Yala Swamp would have been quite noble had the management included in their programme the irrigation of the semi-arid land neighouring the riparian strip. It is in this section of the location that the locals migrated to after Dominion took over and transformed the arable land (Area I) for large scale mechanized farming.

This study shares the views held by Barbier and Strand (2011) and hold that food security can only be made possible through proactive and progressive policies and measures that would ensure access to food and reduction in the number of the hungry. However, when a community that has been relying solely on a wetland for survival is forced to give up the only source of daily food - and left with no alternative source - then one wonders if the national food policies are proactive and progressive enough to protect that rural community from exploitation by entrepreneurs and political leaders.

The aspect of food security is closely tied to that of availability of land. In Kenya land is the one most prized asset that no individual or household wants to lose. Establishing the relationship between Dominion Irrigation Project and food security among households in South Central Alego would most certainly require answers to pertinent questions about the ownership, allocation and lease of the agricultural land known as Area I. With $98 \%$ of the household heads declaring that they do not have enough land to till for subsistence use; $83 \%$ revealing that they do not have adequate pasture for their livestock; $96.9 \%$ stating that the food situation in their households was better before the transformation of the Wetland as opposed to the period after the transformation - then all factors considered, this is a situation that calls for enforcement of measures that govern lease of wetlands to investors (local or foreign). Kenya being an agricultural country, there cannot be food security for the rural population if these people do not have land to plough.
Land ownership is such an emotive issue in Kenya to the extent that a discussion on land requires sobriety and wisdom especially on the part of the person seeking information. When the study sought answers on matters pertaining to availability, ownership and lease of Area I, the reactions were varied and all very disheartening: some respondents stared in silence at the rice fields, then their gaze seemed to go beyond the fields and back before finding words to explain their dilemma; some burst out, talking incoherently and almost endlessly - seemingly expecting the interviewer to tell them the Project is winding up; some were in control of their emotions and took time to explain their very deep feelings pertaining to the issue of lease of 'their' land for a period of 25 years; some did not have much to say other that ask a rhetorical question: “... without land where can food come from ...? It was no surprise therefore when $84.3 \%$ of the respondents asserted that the food situation in their households is currently very bad and apportioned blame on the irrigation activities carried out by Dominion Project in Yala Swamp since 2003.

\section{Conclusion and Recommendation}

Population expansion and the need for fertile agricultural land is a major factor that leads to population migration towards wetlands. This study holds the view that for investors it is the desire to extract as much as they can of the natural resource that drives them to occupy and transform wetlands. The study saw the natural and human capital in South Central Alego as appropriate for subsistence and commercial agriculture as well as agricultural intensification for increased production for a variety of food crops. This would contribute to enhanced rural livelihoods and poverty reduction. However, it is necessary to add that for optimal success, especially with the human capital, all stakeholders must be given a chance to fully participate in the planning and implementation, and outputs must be seen to benefit all parties. Local participation would hence ensure that transformation of wetlands into large agricultural investments benefit the locals. The unending state of discontent in Yala Swamp attest to the view held by this study that MNCs sometimes find themselves at loggerheads with the host communities on the accusation that they implement different projects other than the ones proposed in the development plan given to their respective partners.

Considering that Dominion is an agricultural enterprise and that the Project started work in the Wetland ostensibly to ensure food security, it was necessary to find out if the Project had indeed ensured food security for the households. The study concludes that the activities of Dominion Irrigation Project have led to food insecurity in the location. It shares the view of the residents who were categorical that if Dominion really wanted to ensure food security in the area then there was only one solution - renegotiate the lease agreement and surrender Area I back to the locals.

Management of Natural Resources and the aspect of Participatory Development needs local knowledge, beyond that of outside experts, and the local communities have it. It is crucial, though, that the inclusion of local knowledge is done early in the process for participation to be effective. This would hence enable mitigations to be planned in an all-

\section{Volume 4 Issue 12, December 2015}




\section{International Journal of Science and Research (IJSR) \\ ISSN (Online): 2319-7064}

Index Copernicus Value (2013): 6.14 | Impact Factor (2014): 5.611

inclusive manner by the different parties as a way to prevent rather than to adjust impacts afterwards. Political and religious leaders would then need to change their attitude and approach on the vital role they are expected to play at the negotiation tables on behalf of the populations they represent. They will have to provide democratic space and allow residents to freely participate and discuss issues that affect their livelihoods - like food security.

Use of natural resource bases (like wetlands) by international companies should be strictly guided by the existing institutional frameworks in order to enable sustainable utilization of the resource. Also, there should be a requirement for MNCs to know their host communities (lifestyle) and to avoid activities that degrade the cultural inclinations of these communities (like digging out graves and destroying cultural/spiritual sites). The Kenyan citizenry on its part need to be sensitized by County Governments to know what to expect and what not to expect from local and international investors.

\section{References}

[1] Food and Agricultural Organization (FAO) (2012). Food Security Statistics.

[2] Kiome, R. (2009). Food Security in Kenya. Ministry of Agriculture. Republic of Kenya, 2009.

[3] Ngigi, S.N. (2002). The Changing Face of Irrigation in Kenya. Opportunities for Anticipating Change in Eastern and Southern Africa, Review of Irrigation Development in Kenya. International Water Management Institute.

[4] Barbier, E. B. and Strand, I. (2011). Valuing Mangrove Fishery Linkages: A case study of Compeche, Mexico. Environmental and Resource economics. Vol. 12,

[5] Department for International Development (DFID) (2002). Better Livelihoods for Poor People: The role of Agriculture. London

[6] Swallow, B. (2004). Reversing Environment Degradation and Agricultural Deadline in the Nyando River Basin. Nairobi: World Agro-forestry Centre.

[7] National Environmental Management Authority. (2005). NEMA and Community': Lokapel Community Natural Resources Management Plan, NEMA News. NGOs and CBOs Focus. Nairobi: NEMA, pp 18-19

[8] Maltby, E., (2009). Functional Assessment of Mangrove Fishery Linkages: a case study of Compeche, Mexico. Environmental and Resource Economics. Vol. 12,

[9] Terer, T., Ndiritu, G. and Gichuki ,N. (2004). Socioeconomic values and traditional strategies of managing wetland resources in lower Tana River, Kenya.

[10]Ramsar Convention Secretariat (2007). Wise use of Wetlands: A Conceptual Framework for the wise use of Wetlands. 3rd edition, vol.1

[11] Prossor, R. (1995). Managing Environmental System. Stockholm Environmental Institute.

[12] Adams, M. (1995). Wetland and floodplain development in dry land Africa: People and Environment. Sussex, UK. John Wiley \& Sons, Ltd.

[13] Olson, M. (2006). Georgia's Wetland Treasurers. Georgia: Graphic Creations Publication.
[14]Landberg, H. (1994). Population, Economic Development and the Environment. New York: Oxford University Press.

[15] Sarre, P. and Blunden, J. (1996). Environment, Population and Development. London: Hodder and Stoughton.

[16]Digby, B. (2000). Changing Environments. Oxford: Heinemann Educational Publishers.

[17]Department of Resource Surveys and Remote Sensing (DRSRS) (1992). East Africa Educational Publishers Ltd. People and Environment.

\section{Author Profile}

Pariciah I. Owiyo holds a Masters Degree in Sociology (Community Development and Project Management) from Egergon University, Kenya (2015) and a B.A Degree in Sociology from Moi University, Kenya (2010). She works with Moi University and is involved in Project Management at different levels. 